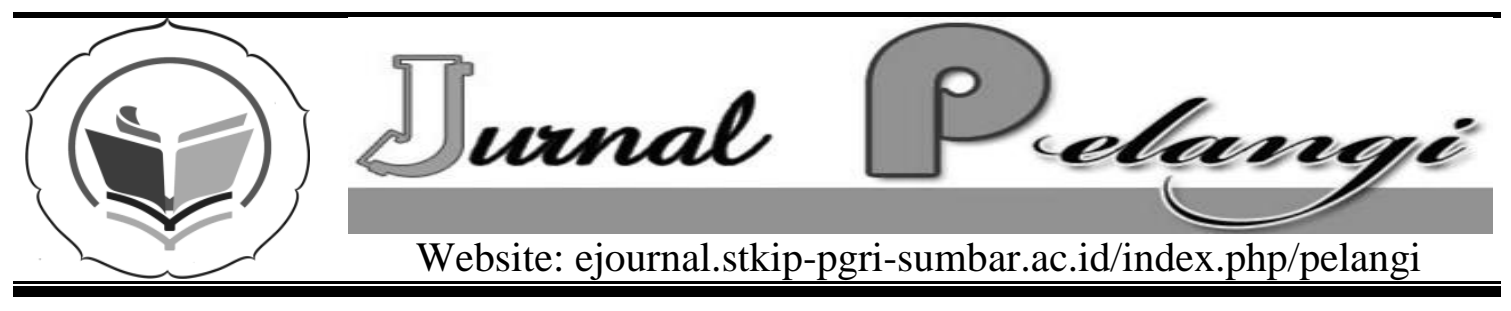

\title{
UPAYA GURU BIMBINGAN DAN KONSELING MEMPERSIAPKAN PESERTA DIDIK DALAM MEMILIH SEKOLAH LANJUTAN DI SMP NEGERI KOTA PADANG
}

\author{
Septya Suarja \\ STKIP PGRI Sumatera Barat \\ septya.suarja99@gmail.com
}

INFO ARTIKEL

Diterima: 3 April 2015

Disetujui: 22 Juni 2015

Kata Kunci:

Upaya Guru BK, Memilih Sekolah Lanjutan
Keywords:

Efforts Teacher BK, Choosing Secondary Schools
Abstrak

Satuan pendidikan SMP memiliki peran penting dalam membantu kesuksesan peserta didik dalam memilih sekolah lanjutan. Untuk itu proses pelaksanaan pelayanan difokuskan pada bidang pengembangan pribadi dan belajar peserta didik. Penelitian ini bertujuan untuk mengungkap, mendeskripsikan dan menganalisis upaya guru BK mempersiapkan peserta didik dalam memilih sekolah lanjutan. Penelitian ini termasuk penelitian deskriptif analisis dengan pendekatan kuantitatif. Sampel 30 guru BK dari delapan sekolah SMPN Kota Padang yang dipilih dengan teknik purposive sampling. Instrumen yang digunakan yakni dengan model skala Likert. Data dianalisis dengan menggunakan teknik statistik sederhana (teknik persentase). Berdasarkan temuan penelitian dapat disimpulkan upaya guru BK mempersiapkan peserta didik dalam memilih sekolah lanjutan berada pada kategori cukup. Dengan demikian upaya guru BK perlu ditingkatkan dari program pelayanan $B K$ dan pelaksanaan pelayanan $B K$.

\section{Abstract}

Unit secondary education has an important role in helping the success of the students in choosing a school. For the process of implementation of the service is focused on the field of personal development and learning of learners. This study aims to reveal, describe and analyze the efforts of BK teachers prepare students in select schools. This study included descriptive analysis with quantitative approach. 30 samples from 8 school teachers BK SMP Padang selected by purposive sampling technique. Instruments used the Likert scale model. Data were analyzed using simple statistical techniques (techniques percentage). Based on the findings of this study 
concluded efforts BK teachers prepare students in select schools in the category enough. Thus the efforts of teachers needs to be improved $B K B K$ service program and service implementation $B K$.

\section{PENDAHULUAN}

Pada hakekatnya proses pendidikan harus memperhatikan karakteristik peserta didik. Undang-undangRepublik Indonesia No. 20 Tahun 2003 tentang Sistem Pendidikan Nasional Bab I pasal 12 ayat (1b) menyatakan "setiap peserta didik pada setiap satuan pendidikan berhak mendapatkan pelayanan pendidikan sesuai dengan bakat, minat dan kemampuannya". Isi pasal 12 ayat (1b) memberikan pedoman kepada seluruh pelaku pendidikan, Terutama guru untuk memperhatikan dan menempatkan perbedaan karakteristik peserta didik dalam melakukan proses pendidikan. Guru BK sangat berperan memperhatikan dan menempatkan perbedaan karakteristik peserta didik dalam pendidikan.

Dalam proses pendidikan yang dilakukan, memahami perbedaan perkembangan arah minat dan bakat peserta didik. Agar arah kesiapan pemilihan sekolah lanjutan akan efektif jika diberlakukan mulai dari pendidikan dasar, yaitu tingkat SD dan SMP. Dengan diketahui dan terjadi proses arah pemilihan sekolah lanjutan pada tingkat dasar akan sangat membantu peserta didik dan guru untuk memilih tingkatan pendidikan yang lebih tinggi, yaitu SMA/SMK dan juga perguruan tinggi.

Satuan pendidikan SMP memiliki peran penting dalam membantu kesuksesan peserta didik dalam menempuh pendidikan lanjutan dan karir. Proses pendidikan di SMP menjadi landasan ke mana arah pemilihan sekolah lanjutan peserta didik pada pendidikan lanjut. Menurut Wina Sanjaya (2008:127) tujuan dari pendidikan dasar khususnya SMP yaitu untuk meletakkan dasar kecerdasan, pengetahuan, kepribadian, akhlak mulia, serta keterampilan untuk hidup mandiri dan mengikuti pendidikan lanjut. Peserta didik SMP dipersiapkan untuk melanjutkan ke pendidikan tingkat menengah.

Menurut pendapat Ginzberg (dalam Santrock, 2003:483) peserta didik SMP berada pada fase pengembangan (growth) yang meliputi masa kecil sampai usia 15 tahun. Dalam fase ini anak mengembangkan bakat-bakat, minat, kebutuhan dan potensi yang akhirnya dipadukan dalam strukur konsep diri. Fenonema yang terjadi saat ini peserta didik bingung dengan arah pemilihan sekolah lanjutan dan orangtua lebih berperan dalam pemilihan sekolah lanjutan. Kondisi ini menyebabkan peserta didik SMP terkendala dalam memilih sekolah lanjutan yang sesuai dengan bakat dan minatnya.

Dalam proses pendidikan, pihak yang dianggap paling berkompeten membantu peserta didik memahami bakat dan minat serta mengarahkan pemilihan studi lanjut adalah guru BK. 
Upaya yang dilakukan oleh guru BK antara lain melalui bidang pelayanan yang dikenal dengan layanan bimbingan dan konseling. Pelayanan bimbingan dan konseling merupakan layanan yang terdiri dari berbagai konsep dan metode serta disesuaikan dengan kebutuhan peserta didik.

Penyelenggaraan pelayanan BK di SMP merupakan upaya sekolah dalam pengembangan bakat dan minat peserta didik. Sehingga penyelenggaraan pelayanan BK di SMP sepenuhnya memperhatikan karakteristik peserta didik di SMP. Dengan demikian guru BK dapat membantu peserta didik dalam menentukan pilihan yang tepat dan benar dalam memilih studi lanjutan untuk jenjang berikutnya.

Penelitian ini secara umum bertujuan untuk mendeskripsikan dan menganalisis upaya guru $\mathrm{BK} /$ konselor mempersiapkan peserta didik dalam memilih sekolah lanjutan. Secara khusus tujuan yang ingin dicapai sebagai berikut:(1) upaya guru BK dalam perencanaan program pelayanan $\mathrm{BK}$ untuk mempersiapkan peserta didik memilih sekolah lanjutan, (2) upaya guru BK dalam pelaksanaan pelayanan BK untuk mempersiapkan peserta didik dalam memilih sekolah lanjutan, 3) upaya guru BK mempersiapkan peserta didik dalam memilih sekolah lanjutan sesuai dengan rekomendasi dari Guru BK.

\section{METODE PENELITIAN}

Penelitian ini termasuk penelitian deskriptif dengan pendekatan
kuantitatif.Sampel 30 guru BK dari 8 sekolah SMPN Kota Padang yang dipilih dengan teknik purposive sampling.Instrumen yang digunakan dengan model skala Likert.Data dianalisis dengan menggunakan teknik statistik sederhana (teknik persentase).

Instrumen penelitian untuk mengukur upaya guru BK mempersiapkan peserta didik dalam memilih sekolah lanjutan dengan reabilitas 0,948, data diolah secara SPSS versi 20.00 dengan menggunakan Alpha Cronbach.

\section{HASIL DAN PEMBAHASAN}

Deskripsi Data Upaya Guru BK Mempersiapkan Peserta Didik dalam Memilih Sekolah Lanjutan

Hasil pengolahan data penelitian disajikan pada Tabel 1. Berdasarkan tabel 1 dipahami bahwa upaya guru BK mempersiapkan peserta didik dalam memilih sekolah lanjutan berada pada kategori cukup dengan rata-rata 169,6 atau sebesar $67,8 \%$.

Berdasarkan tabel 1 dipahami bahwa untuk mempersiapkan peserta didik dalam memilih sekolah lanjutan dari program pelayanan BK berada pada kategori cukup dengan rata-rata 51,5 atau sebesar 59,47\%. Indikator program pelayanan BK berdasarkan kebutuhan dan materi program pelayanan BK untuk persiapan memilih sekolah lanjutan berada pada kategori cukup, sedangkan adanya program pelayanan pemilihan sekolah lanjutan berada pada kategori kurang baik. 
Tabel 1. Deskripsi Upaya Guru BK Mempersiapkan Peserta Didik dalam Memilih Sekolah Lanjutan ( $=30)$

\begin{tabular}{|c|c|c|c|c|c|c|c|c|c|}
\hline \multirow{2}{*}{ Sub Variabel } & \multicolumn{8}{|c|}{ Skor } & \multirow{2}{*}{ Ket } \\
\hline & Indikator & Ideal & Max & Min & Total & Mean & $\%$ & $\mathrm{Sd}$ & \\
\hline \multirow{4}{*}{ Program Pelayanan BK } & Program Pelayanan BK Berdasarkan Kebutuhan & 25 & 25 & 11 & 445 & 17,12 & 59,33 & 2,88 & Cukup \\
\hline & $\begin{array}{l}\text { Materi Program Pelayanan BK untuk Persiapan } \\
\text { Memilih Sekolah Lanjutan }\end{array}$ & 15 & 15 & 6 & 266 & 10,2 & 59,11 & 2,42 & Cukup \\
\hline & Adanya Program Pelayanan Pemilihan Sekolah Lanju & 35 & 22 & 14 & 465 & 17,88 & 44,28 & 2,03 & Kurang Baik \\
\hline & Total Program Pelayanan BK & 75 & 69 & 38 & 1338 & 51,5 & 59,47 & 12,4 & Cukup \\
\hline \multirow{6}{*}{ Pelaksanaan Pelayanan BK } & Pengumpulan Data dan Informasi & 30 & 21 & 13 & 434 & 16,7 & 48,22 & 2,94 & Cukup \\
\hline & $\begin{array}{l}\text { Layanan Informasi/Orientasi Arah Pemilihan } \\
\text { Sekolah Lanjutan }\end{array}$ & 30 & 23 & 13 & 463 & 17,81 & 51,44 & 3,27 & Cukup \\
\hline & $\begin{array}{l}\text { Indentifikasi dan Pemantapan Arah Pemilihan } \\
\text { Sekolah Lanjutan }\end{array}$ & 20 & 16 & 10 & 351 & 13,5 & 58,5 & 1,75 & Baik \\
\hline & Penyesuaian Arah Pemilihan Sekolah Lanjutan & 20 & 18 & 10 & 337 & 12,96 & 56,17 & 2,24 & Cukup \\
\hline & Monitoring dan Tindak Lanjut & 10 & 10 & 4 & 181 & 6,96 & 60,33 & 1,46 & Baik \\
\hline & Total Pelaksanaan Pelayanan BK & 110 & 64 & 39 & 1322 & 50,85 & 40,06 & 12,12 & Kurang Baik \\
\hline \multirow{3}{*}{ Rekomendasi dari Guru BK } & $\begin{array}{l}\text { Analisi Arah Peminatan/Pola Pemilihan Sesuai } \\
\text { Potensi, Minat dan Prestasi Belajar }\end{array}$ & 35 & 19 & 14 & 421 & 16,19 & 40,09 & 1,98 & Kurang Baik \\
\hline & \begin{tabular}{|l} 
Rekomendasi dari Guru BK Berdasarkan Hasil \\
Belajar, Hasil UN dan Prestasi Non Akademik
\end{tabular} & 30 & 22 & 15 & 473 & 18,2 & 52,55 & 2,23 & Cukup \\
\hline & Total Rekomendasi dari Guru BK & 65 & 51 & 38 & 1177 & 45,3 & 60,36 & 8,92 & Baik \\
\hline & Total Keseluruhan & 250 & 202 & 140 & 5088 & 169,6 & 67,8 & 21,16 & Cukup \\
\hline
\end{tabular}

Tabel 2. Persentase Upaya Guru BK Mempersiapkan Peserta Didik dalam Memilih Sekolah Lanjutan $(\mathrm{N}=30)$

\begin{tabular}{|c|c|c|c|c|}
\hline Variobel & Interw & Kategari & $\mathbf{F}$ & $\%$ \\
\hline \multirow{6}{*}{$\begin{array}{l}\text { Upaya Gum BK } \\
\text { Mempersiaplian } \\
\text { PesertaDidik dalam } \\
\text { Memilih Selmolah } \\
\text { Ianjutan }\end{array}$} & $\geq 210$ & Sangat Baik & (1) & $\mathbf{0}$ \\
\hline & $170-209$ & Baik & 13 & 43,33 \\
\hline & $130-169$ & Cring & 17 & 56,67 \\
\hline & 90-129 & Kmirang Bailk & 0 & 0 \\
\hline & $\leq 89$ & Tidak Balk & 0 & 0 \\
\hline & & Fomlah & 30 & 100 \\
\hline
\end{tabular}

Selanjutnya tabel 1 dipahami bahwa pelaksanaan pelayanan BK berada pada kategori kurang baik dengan rata-rata 50,85 atau sebesar 40,06\%. Pengumpulan data dan informasi, layanan informasi/orientasi arah pemilihan sekolah lanjutan, dan penyesuaian arah pemilihan sekolah lanjutan berada pada kategori cukup. Sedangkan identifikasi dan pemantapan arah pemilihan sekolah lanjutan dan monitor dan tindak lanjut berada pada kategori baik.

Berdasarkan tabel 1 dipahami bahwa rekomendasi dari guru BK berada pada kategori baik dengan rata-rata 45,3 atau sebesar 60,36\%. Indikator analisis arah pemilihan sekolah lanjutan berada pada kategori kurang baik dan rekomendasi dari guru BK berdasarkan hasil belajar, hasil UN dan prestasi non akademik berada pada kategori cukup.

Gambaran keseluruhan persentase tentang upaya guru BK mempersiapkan peserta didik dalam memilih sekolah lanjutan dapat dilihat pada tabel 2 . Berdasarkan tabel 2 dipahami bahwa upaya guru BK mempersiapkan peserta didik dalam memilih sekolah lanjutan berada pada kategori cukup dengan frekuensi 17 responden atau sebesar $56,67 \%$.

Gambaran keseluruhan persentase tentang upaya guru BK mempersiapkan peserta didik dalam memilih sekolah lanjutan berdasarkan sub variabel dapat dilihat pada Tabel 3. 
Tabel 3. Persentase Upaya Guru BK Mempersiapkan Peserta Didik dalam Memilih Sekolah Lanjutan Dilihat dari Sub Variabel $(\mathrm{N}=30)$

\begin{tabular}{|c|c|c|c|c|}
\hline Sub Variabel & Interval & Kategori & $\mathbf{F}$ & $\%$ \\
\hline \multirow{6}{*}{$\begin{array}{c}\text { Program Pelayanan } \\
\text { BK }\end{array}$} & $\geq 59$ & Sangat Baik & 6 & 20 \\
\hline & $51-58$ & Baik & 10 & 33,33 \\
\hline & $39-50$ & Cukup & 13 & 43,34 \\
\hline & $27-38$ & Kurang Baik & 1 & 3,33 \\
\hline & $\leq 26$ & Tidak Baik & $\mathrm{O}$ & $\mathbf{O}$ \\
\hline & & Jumlah & 30 & 100 \\
\hline \multirow{7}{*}{$\begin{array}{l}\text { Pelaksanaan } \\
\text { Pelayanan BK }\end{array}$} & Interval & Kategori & $\mathbf{F}$ & $\%$ \\
\hline & $\geq 93$ & Sangat Baik & $\mathrm{O}$ & $\mathbf{O}$ \\
\hline & $75-92$ & Baik & $\mathbf{O}$ & $\mathbf{O}$ \\
\hline & $58-74$ & Cukup & 7 & 23,33 \\
\hline & $40-57$ & Kurang Baik & 23 & 76,67 \\
\hline & $\leq 39$ & Tidak Baik & $\mathrm{O}$ & $\mathrm{O}$ \\
\hline & & Jumlah & 30 & 100 \\
\hline \multirow{7}{*}{$\begin{array}{c}\text { Rekomendasi dari } \\
\text { Guru BK }\end{array}$} & Interval & Kategori & $\mathbf{F}$ & $\%$ \\
\hline & $\geq 55$ & Sangat Baik & $\mathrm{O}$ & $\mathbf{O}$ \\
\hline & $45-54$ & Baik & 19 & 63,33 \\
\hline & $33-34$ & Cukup & 11 & 36,67 \\
\hline & $24-33$ & Kurang Baik & $\mathrm{O}$ & $\mathbf{O}$ \\
\hline & $\leq 23$ & Tidak Baik & $\mathrm{O}$ & $\mathrm{O}$ \\
\hline & & Jumlah & 30 & 100 \\
\hline
\end{tabular}

Berdasarkan tabel 3 dipahami bahwa sub variabel upaya guru BK mempersiapkan peserta didik dalam memilih sekolah lanjutan yaitu: (1) program pelayanan $\mathrm{BK}$ berada pada kategori cukup dengan frekuensi 13 responden atau dengan $43,34 \%$, (2) pelaksanaan pelayanan BK berada pada kategori kurang baik dengan frekuensi 23 responden atau dengan $76,67 \%$, (3) rekomendasi dari guru BK berada pada kategori baik dengan frekuensi 19 responden atau dengan $63,33 \%$.

Upaya yang dapat dilakukan guru BK mempersiapkan peserta didik dalam memilih sekolah lanjutan yaitu: (a) guru BK membuat pedoman untuk peserta didik SMP, (b) menyiapkan informasi berkaitan dengan pendidikan lanjutan secara lengkap, (c) membuat format layanan tentang studi lanjut. Berdasarkan temuan tersebut dapat disimpulkan upaya guru BK mempersiapkan peserta didik dalam memilih sekolah lanjutan perlu ditingkatkan dari program pelayanan BK dan pelaksanaan pelayanan BK.

Upaya Guru BK Mempersiapkan Peserta Didik dalam Memilih Sekolah Lanjutan dilihat dari Program Pelayanan BK

Upaya guru BK untuk mempersiapkan peserta didik dalam memilih sekolah lanjutan berada pada kategori cukup dengan 56,67\%. Hal ini perlu ditingkatkan menjadi lebih baik agar tercapai tujuan yang optimal. Adapun yang harus dilakukan guru BK dalam penyusunan program pelayanan BK adalah menganalisis kebutuhan peserta didik, menyusun program pelayanan BK, menyusun rencana pelaksanaan dan merencanakan sarana dan biaya penyelenggaraan program pelayanan BK. Sebagaimana menurut Syamsu Yusuf (2009:69) aktifitas yang dirancang dalam penyusunan program meliputi: identifikasi kebutuhan konseli (need assessment), perumusan tujuan, 
pengembangan komponen program, penyusunan deskripsi kerja para personel pelaksana, penetapan anggaran/ pembiayaan, penyiapan sarana atau fasilitas yang mendukung penyelenggaraan program.

Hal ini dipertegas Jamal Ma'mur, A (2010:136) penyusunan pelayanan BK disusun berdasarkan kebutuhan peserta didik (need assessment) yang diperoleh melalui aplikasi instrumentasi. Dalam identifikasi dan merumuskan kebutuhan peserta didik dalam memilih sekolah lanjutan guru BK perlu memperhatikan yaitu: (1) mengkaji kebutuhan atau masalah kesiapan peserta didik dalam memilih sekolah lanjutan, seperti: karakteristik peserta didik (aspek fisik, kecerdasan, motif belajar, sikap, kebiasaan belajar, minat, masalah yang dialami dan kepribadian), tugas-tugas perkembangan (2) mengkaji harapan sekolah dan orangtua terhadap peserta didik, (3) ketersediaan fasilitas pendukung (Syamsu Yusuf, 2009:70).

Selanjutnya program pelayanan BK sekolah menengah pertama (SMP) dalam Peraturan Menteri Pendidikan dan Kebudayaan Republik Indonesia Nomor 111 Tahun 2014 tentang Bimbingan dan Konseling pada Pendidikan Dasar dan Pendidikan Menengah, disebutkan bahwa setiap peserta didik satu dengan yang lainnya berbeda kecerdasan, bakat, minat, kepribadian, kondisi fisik dan latar belakang keluarga serta pengalaman belajar yang menggambarkan adanya perbedaan masalah yang dihadapi peserta didik sehingga memerlukan layanan BK.
Berdasarkan penjelasan terdahulu dapat dipahami bahwa aktifitas dalam penyusunan program BK meliputi identifikasi kebutuhan, perumusan tujuan, pengembangan komponen program, penyusunan deskripsi kerja personel BK, penetapan anggaran, penyiapan sarana dan prasarana yang mendukung penyelenggaraan program.

\section{Upaya Guru BK Mempersiapkan Peserta Didik dalam Memilih Sekolah Lanjutan Dilihat dari Pelaksanaan Pelayanan BK}

Berdasarkan hasil pengolahan data yang ada di lapangan maka dapat dikemukakan bahwa upaya guru BK mempersiapkan peserta didik dalam memilih sekolah lanjutan dilihat dari pelaksanaan pelayanan BK berada pada kategori kurang baik dengan jumlah 76,67\%. Upaya guru BK mempersiapkan peserta didik dalam memilih sekolah lanjutan dilihat dari pelaksanaan pelayanan BK perlu ditingkatkan menjadi lebih baik agar pelayanan BK dapat berjalan lebih baik dan tercapai hasil yang maksimal bagi peserta didik. Tugas guru BK dalam melaksanakan pelayanan secara maksimal berdasarkan kebutuhan, potensi, bakat, minat dan kepribadian peserta didik.

Hal ini dipertegas Wardati dan Mohammad Jauhar (2011: 141) tugas guru BK membantu peserta didik dalam: a) pengembangan kehidupan pribadi, yaitu bidang pelayanan yang membantu peserta didik dalam memahami, menilai bakat dan minat, b) pengembangan kehidupan sosial, yaitu bidang pelayanan 
yang membantu peserta didik dalam memahami dan menilai serta mengembangkan kemampuan hubungan sosial, dinamis, berkeadilan dan bermartabat, c) pengembangan kemampuan belajar, yaitu bidang pelayanan yang membantu peserta didik mengembangkan kemampuan belajar untuk mengikuti pendidikan sekolah secara mandiri, d) pengembangan karir, yaitu bidang pelayanan yang membantu peserta didik dalam memahami dan menilai informasi, serta memilih dan mengambil keputusan karir.

Sejalan dengan pendapat di atas, kriteria keberhasilan dalam pelayanan BK kepada peserta didik, menurut Koestoer Partowisastro (dalam Amirah Diniaty, 2012:78) diantaranya sebagai berikut: a) menerima diri sendiri, baik mengenai kekuatannya maupun kelemahan-kelemahannya, sehingga dapat membuat rencana untuk menentukan cita-cita dan membuat keputusannya, b) memperoleh pengetahuan dan pemahaman yang benar mengenai dunia sekitar, c) dapat memahami dan memecahkan masalahnya, d) dapat memilih secara tepat dan menyelesaikan program studi dan berhasil sesuai dengan tingkat kemampuannya, e) dapat memilih pendidikan lanjutan secara tepat sesuai dengan bakat, minat, dan kemampuannya. Kriteria tersebut tidak lepas dari upaya guru BK dalam melaksanakan pelayanan optimal untuk mempersiapkan peserta didik dalam memilih sekolah lanjutan.
Selanjutnya ada beberapa asas mengenai pelaksanaan bimbingan karir atau persiapan memilih sekolah lanjutan diantaranya: 1) program dirancang untuk melayani kebutuhan peserta didik, 2) program bimbingan karir merupakan bagian terpadu dari keseluruhan program pendidikan di sekolah, 3) tujuan program harus dirumuskan secara jelas dan eksplisit, 4) pelaksanaan program perlu melibatkan seluruh staf sekolah, 5) personal bimbingan karir perlu diidentiikasi dan tugas-tugas serta tanggung jawabnya dirumuskan, 6) segala sumber daya perlu ditemukan untuk mencapai tujuan program, 7) dari keperluan-keperluan untuk penyelenggaraan bimbingan karir adalah data pribadi peserta didik untuk pemahaman diri, dan bahan informasi untuk perencanaan pendidikan dan pengambilan keputusan karir, 8) penerapan rancangan sistem dalam pengembangan program dan pemecahan masalah pengelolaan, 9) dukungan dan pelibatan masyarakat sekitar demi kelancaran penyelenggaraan program dan ketercapaian tujuan (Munandir, 1996:248).

Penjelasan terdahulu dapat dipahami bahwa pelaksanaan pelayanan BK untuk membantu peserta didik dalam memilih sekolah lanjutan beberapa hal yang perlu diperhatikan yakni tugas guru BK membantu peserta didik terhadap pengembangan pribadi, pengembangan kehidupan sosial, pengembangan kemampuan belajar, serta pengembangan karir. Agar pelaksanaan pelayanan BK maksimal perlu memperhatikan 
kriteria keberhasilan pelayanan BK untuk peserta didik, dengan memperhatikan beberapa asas pelaksanaan bimbingan karir/persiapan memilih sekolah lanjutan.

\section{Upaya Guru BK Mempersiapkan} Peserta Didik dalam Memilih Sekolah Lanjutan Dilihat dari Rekomendasi dari Guru BK

Berdasarkan hasil pengolahan data yang ada di lapangan maka dapat dikemukakan bahwa upaya guru BK mempersiapkan peserta didik dalam memilih sekolah lanjutan dilihat dari rekomendasi dari guru BK berada pada kategori baik dengan jumlah 63,33\%. Ini artinya $36,67 \%$ guru BK perlu mempersiapkan peserta didik dalam memilih sekolah lanjutan untuk ditingkatkan menjadi lebih baik. Dalam rekomendasi, guru BK perlu mengungkap data yang perlu dipertimbangkan dalam penegasan arah pemilihan sekolah lanjutan melalui alternatif pola penentuan di SMA.

Hal ini sesuai dengan Penelitian Tindakan Bimbingandan Konseling (PTBK) yang dilakukan selama empat bulan dalam Tahun Pelajaran 2012-2013 ini, dimaksudkan untuk membantu peserta didik dalam meningkatkan pemahaman studi lanjutnya melalui metode debat aktif dalam layanan bimbingan kelompok. Setelah melalui dua kali siklus, hasilnya peserta didik berani membuat keputusan pilihan studi lanjutnya berdasarkan pemahaman diri daninformasi yang tepat tentang pilihan studi lanjutnya. Berdasarkan hasil penelitian, guru disarankanuntuk menggunakan metode pembelajaran yang mengajak peserta didik lebih aktif dalam menggaliinformasi tentang pilihan studi lanjut sehingga membuat peserta didik lebih aktif, mau berbagi informasidan menyenangkan yang pada akhirnya siswa dapat membuat keputusan berdasarkan pemahamanyang dimilikinya (Cahyo Purnomo, 2014).

Kementerian Pendidikan dan Kebudayaan (2014:61) menjelaskan sebagai berikut: Pada akhir studi di SMP, peserta didik perlu dilengkapi dengan rekomendasi arah pemilihan sekolah lanjutan yang dikembangkan selama studi di SMP. Materi rekomendasi yang dimaksud itu merupakan hasil akhir proses yang telah dilakukan melalui langkah-langkah pokok untuk mengungkap data tentang aspek-aspek yang dipertimbangkan dalam penegasan atau penentuan arah pemilihan sekolah lanjutan melalui alternatif pola penentuan pemilihan sekolah lanjutan yang ada, dan berbagai informasi tentang realisasi penegasan aturan di SLTA.

Penjelasan terdahulu dapat dipahami peserta didik perlu dilengkapi dengan rekomendasi dari guru BK yang dikembangkan selama studi di SMP. Rekomendasi arah pemilihan sekolah lanjutan mempertimbangkan penentuan arah pemilihan sekolah lanjutan melalui alternatif pola penentuan pemilihan sekolah lanjutan di SMA. 


\section{KESIMPULAN DAN SARAN}

Berdasarkan temuan dan analisis hasil penelitian mengenai upaya guru BK mempersiapkan peserta didik dalam memilih sekolah lanjutan di SMP Negeri Kota Padang dilihat dari program pelayanan BK, pelaksanaan pelayanan BK, dan rekomendasi dari guru BK dapat disimpulkan secara umum upaya guru BK mempersiapkan peserta didik dalam memilih sekolah lanjutan berada pada kategori cukup.

\section{UCAPAN TERIMAKASIH}

Terbitnya tulisan ini tidak terlepas dari bantuan berbagai pihak, untuk itu penulis mengucapkan terima kasih yang sebesar-besarnya kepada Pihak STKIP PGRI Sumatera Barat khususnya pengelola jurnal Pelangi yang telah memberikan kesempatan kepada penulis untuk mempublikasikan hasil penelitian di jurnal Pelangi. Selanjutnya penulis juga berterima kasih kepada para penyumbang sumber insirasi yang telah memberikan inspirasi bagi penulis untuk mengutip atau menggunakan tulisannya sebagai bahan referensi.

\section{DAFTARPUSTAKA}

Amirah Diniaty. 2012. Evaluasi Bimbingan Konseling. Pekanbaru: Zanafa.

Cahya Purnomo. 2014. Meningkatkan Pemahaman Studi Lanjut melalui Metode Debat Aktif dalam Layanan Bimbingan Kelompok.Jurnal (diakses Agustus 2014).
Jamal Ma'mur Asmani.2010. Panduan Efektif Bimbingan dan Konseling di Sekolah.Jogjakarta: Diva Press.

Kementerian Pendidikan dan Kebudayaan.2014. Panduan Bimbingan dan Konseling Sekolah Menengah Pertama.Jakarta: Direktorat Pembinaan Sekolah Menengah Pertama.

Munandir. 1996. Program Bimbingan Karir di Sekolah. Jakarta: Depdikbud Dirjen Depti Proyek Pendidikan Akademik.

Peraturan Menteri Pendidikan dan Kebudayaan Republik Indonesia Nomor 111 Tahun 2014.Tentang Kurikulum 2013.

Santrock, John. W.Adolescence (Perkembangan

Remaja), terjemahan Shinto B. Adelar \& Sherly Saragih. 2003. Jakarta: Erlangga.

Syamsu Yusuf. 2009. Program Bimbingan dan Konseling. Bandung: Rizqi.

Undang-undang Nomor 20 Tahun 2003. Tentang Sistem Pendidikan Nasional.

Wardati dan Mohammad Jauhar.2011. Implementasi Bimbingan dan Konseling di Sekolah.Surabaya: Prestasi Pustaka.

Wina Sanjaya. 2008. Panduan Penyusunan KTSP Jenjang Pendidikan Dasar danMenengah. Bandung: Prenada Media Group. 